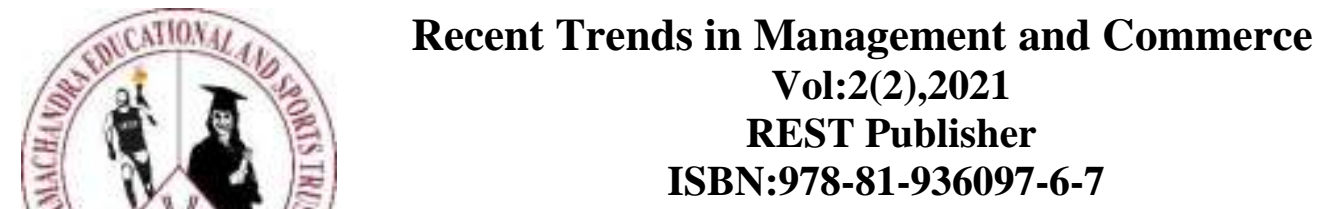

Website: http://restpublisher.com/book-series/rmc/

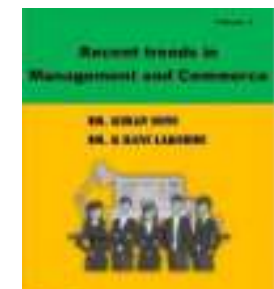

(1)

\title{
Nit - Picking Scrutiny of Nap in Public Sector and Private Sector Banks
}

\author{
Dr. Sambamurthy Padmavathi, N. S. Srimathi \\ Department of Commerce, Shri Shankarlal Sundarbai Shasun Jain College for Women's, Chennai, Tamil Nadu, India. \\ Email: srimathi.n.s@gmail.com
}

\begin{abstract}
The banking system of an economy is of foremost importance for its financial and economic development. It forms the core of the financial sector and plays a critical in transmitting monetary policy impulses to the entire economic system. An important indicator today that determines the solidity of the banks is the Non-Performing Assets. With the introduction of international norms for income recognition, asset classification and provisioning in the banking sector, managing NPA's has been one of the threats facing Indian banks. In this paper "NIT - PICKING SCRUTINY OF NPA IN PUBLIC SECTOR AND PRIVATE SECTOR BANKS", tries to analyze the trend of Total Advances, Net profit, Gross NPA of selected public sector and private sector banks for a particular time span. During the last 10 years, except Punjab National Bank and Bank of Baroda, the remaining banks had a positive trend. It is also inferred that Canara Bank and Yes Bank are efficient than the other banks based on the input and output since then $\lambda=1$.
\end{abstract}

Key Words: Non- Performing Assets, Gross NPA, Net Profit, Total Advances.

\section{Introduction}

A strong banking sector is important for flourishing economy. One of the most important and major roles played by banking sector is that of lending business. It is generally encouraged because it has the effect of funds being transfer from the system to productive purposes that in turn results in economic growth. Since it has both merits and demerits, it has the same with lending business that carries credit risk which arises from the failure of borrower to fulfill its contractual obligations either during the course of a transaction or on a future obligation. The failure of the banking sector may have an adverse effect on the sectors. Non- Performing Assets are one of the major concerns for banks in India. An asset classified as Non- Performing Asset (NPAs) if the borrower for a period not does not pay the dues in the form of principal and interest amount more than $\mathbf{9 0}$ days from March 2004. One cannot ignore the fact that a part of reduction in NPA's is due to the writing off bad loans by banks. The Indian Banks must be careful in providing advances and loans only to credit worthy customers. The golden rule to reduce NPA under this context is "prevention is better than cure". Statement of the problem: The research analyzes to study the strength and weakness of the banking sector as a whole with regard to Non- Performing Assets of banks. Banks from public sector and private sector are studied to overcome the limitations for lending money to different sectors like agriculture, SSI, priority and non- priority sectors and others. This in turn affects the profitability of the banks and the Indian Economic Scenario.

\section{Objectives of the Study}

To compare and analyze the type of Non- Performing Assets (NPA) used and check out the frequency of using such assets in the banks. To observe the techniques adopted to reduce the level of risk of Non- Performing Assets (NPA) in both Public Sector Banks and Private Sector Banks.

\section{Review of Literature}

D. Jayakkodi (2019) in her research paper titled: "a study on non- performing assets of selected public and private sector banks" aimed to compare and examine Gross and Net NPAs of selected banks. This paper mainly aimed at 4 public sector banks- SBI, PNB, Bank of Baroda and Bank of India, 4 private sector banks - ICICI, HDFC, Axis Bank, and Federal Bank. This study is confine for the period of 5 years only. It infers that public sector banks have higher net profit ratio compared to private sector banks. Various statistical tools such as mean, standard deviation, correlation used for the study.

\section{Research Methodology}

According to Kothari, "Research Methodology is a method to analytically explain the research problem". It may be described as a science of analysis how research is done systematically. Descriptive Analytics - Trend Analysis, Gross NPA Ratio. Inferential Analysis - ANOVA, Correlation, Regression. Data Envelopment Analysis (DEA). 


\section{Data Analysis and Interpretation}

Comparison of Advances, Gross NPA and Net Profit of Banks. CHART NO: 4.5.

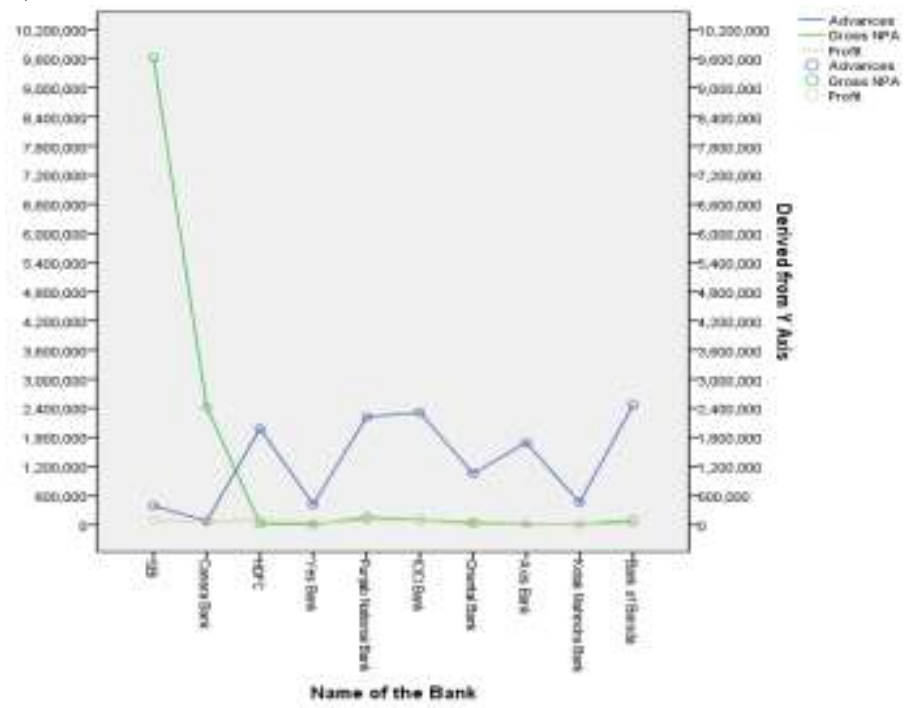

Efficiency of Banks the Data envelopment analysis is a non-parametric technique, which is used to find the efficiency of the Decision making Units-DMU (Banks). The DEA has been performed to find the efficiency of banks with respect to their inputs (Advances, Gross Advances) and Output (Profit)

TABLE 1. Efficiency Score Using CRS Model

\begin{tabular}{|c|c|c|}
\hline \multirow[b]{2}{*}{$\begin{array}{c}\text { DMU } \\
\text { No. }\end{array}$} & \multirow[b]{2}{*}{ DMU(Bank) Name } & CRS \\
\hline & & Efficiency \\
\hline 1 & SBI & 0.47150 \\
\hline 2 & Canara Bank & 1.00000 \\
\hline 3 & HDFC & 0.72958 \\
\hline 4 & Yes Bank & 1.00000 \\
\hline 5 & ICICI Bank & 0.50209 \\
\hline 6 & Axis Bank & 0.07755 \\
\hline 7 & Kotak Mahindra Bank & 0.45878 \\
\hline
\end{tabular}

Inference It is inferred from the above table that Canara Bank and Yes Banks are efficient than the other banks based input and output since then $\lambda=1$ Target to be achieved in Inputs (Advances, Gross NPA)The following table explains the target to be achieved in input (Advances and Gross NPA) to attain the efficiency. Input Target

TABLE 2. Efficient Input Target

\begin{tabular}{|l|l|l|l|l|l|}
\hline \multirow{2}{*}{$\begin{array}{l}\text { DMU } \\
\text { No. }\end{array}$} & \multirow{2}{*}{ Bank Name } & \multicolumn{4}{|c|}{ Efficient Input Target } \\
\cline { 3 - 6 } & $\begin{array}{l}\text { Actual } \\
\text { Advances }\end{array}$ & Advances & $\begin{array}{l}\text { Actual Gross } \\
\text { NPA }\end{array}$ & Gross NPA \\
\hline 1 & SBI & 393323.06 & 185452.47400 & 9619204.55 & 4535470.87144 \\
\hline 2 & Canara Bank & 76944.47 & 76944.47000 & 2417362.309 & 2417362.30900 \\
\hline 3 & HDFC & 1979604.02 & 1444275.64065 & 19864.75 & 14492.88553 \\
\hline 4 & Yes Bank & 420264.41 & 420264.41000 & 3515.48 & 3515.48000 \\
\hline 5 & ICICI Bank & 2315429.72 & 1162546.71232 & 98080.33 & 49244.83958 \\
\hline 6 & Axis Bank & 1692633.63 & 131265.88337 & 23837.34 & 1848.61593 \\
\hline 7 & Kotak Mahindra Bank & 458999.9 & 210580.68802 & 8804.15 & 4039.18163 \\
\hline
\end{tabular}

Inference It is inferred from the above table that the SBI bank has to reduce the advances as 185452.474 instead of 393323.06 to attain the efficiency as the Canara bank. Similarly HDFC bank has to reduce the advances as 1444275.64065instead of 1979604.02to attain the efficiency as the Canara bank. From the above table it is inferred that the ICICI bank has to reduce the advances as 1162546.71232 instead of 2315429.72 to attain the efficiency as Canara bank.

Likewise, in case of Axis bank, the bank has to reduce the advances as 131265.88337 instead of 1692633.63 to attain the efficiency similar to Yes bank. Correspondingly Kotak Mahindra Bank has to reduce the advances as 210580.68802 instead of 458999.9 to attain the efficiency like Yes bank. Target to be achieved in Output (Profit) The following table explains the target to be achieved in output (Profit) to attain the efficiency. 
TABLRE 3. Output Target

\begin{tabular}{|r|l|r|r|}
\hline & & & Efficient Output Target \\
\cline { 4 - 4 } $\begin{array}{r}\text { DMU } \\
\text { No. }\end{array}$ & DMU Name & Actual Profit & Profit \\
\hline 1 & SBI & 96683.72 & 205054.890 \\
\hline 2 & Canara Bank & 49835.59 & 49835.590 \\
\hline 3 & HDFC & 112106 & 153658.625 \\
\hline 4 & Yes Bank & 32608.56 & 32608.560 \\
\hline 5 & ICICI Bank & 90920 & 181084.225 \\
\hline 6 & Axis Bank & 10198.62 & 131508.102 \\
\hline 7 & Kotak Mahindra Bank & 16380.42 & 35704.182 \\
\hline
\end{tabular}

Inference From the above table, it is inferred that the SBI bank can achieve the profit 205054.890 by using the same level input (Advances and Gross NPA) as Canara bank has the actual profit and target output profit are the same. Similarly from the above table it is inferred that the HDFC bank can achieve the profit 153658.625 by using the same level input dvances and Gross NPA) as Canara bank has the actual profit and target output profit are the same. Likewise, in case of ICICI bank, the bank can achieve the profit 181084.225 by using the same level input (Advances and Gross NPA) as Yes bank has the actual profit and target output profit are the same. From the above table, it is inferred that the Axis bank can achieve the profit 131508.102 by using the same input (Advances and Gross NPA) as Yes bank has the actual profit and target output profit are the same. Similarly from the above table it is inferred that Kotak Mahindra Bank can achieve the profit 35704.182 by using the same input (Advances and Gross NPA) as Yes bank has actual profit and target output profit are the same. Findings Of the Study There is a negative impact of Advances on net profit and a positive impact of Gross NPA on net profit. I.e., for the one unit of increment in advances will reflect $1.5 \% \mathrm{v}$ of decrease in profit and vice versa. Similarly, for the one unit of increment in gross NPA will reflect $0.7 \%$ of increase in profit and vice versa. Therefore, the company that gives high advance amount yields less profit. When the companies have high gross NPA will yields more profit. Suggestions for the study RBI should revise existing credit appraisals and monitoring systems. As a part of curative measures, bankers may resort to Compromise Settlement or One Time Settlement. Lok Adalats and Debt Recovery Tribunals are other ways for the recovery of dues. It has observed that Banks are highly resorting to SARFAESI Act for the management of NPA.

\section{Conclusion}

The management of Non- Performing Assets is a daunting task for every Bank in the Banking industry. Results of study through light on the level of Non- Performing Assets of Public Sector and Private Sector Banks. It is a major hurdle faced by the banking industry. Willful defaults, improper processing of loan proposals, poor monitoring and so on are the causes for accounts for becoming NPAs.

\section{References}

1. D. Jayakkodi, "A Study on Non-Performing Assets of Selected Public and Private Sector Banks in India", Intercontinental Journal of Finance Research Review, 2019, ISSN: 2347-1654, Volume: 4, Issue No: 9, PP: 47-53.

2. wWw.Academia.in

3. www. Shodganga.inflibnet.in

4. https://www.ijrsr.com

5. www.researchgate.net 